\title{
Modulation of Antimicrobial Peptide Conformation and Aggregation by Terminal Lipidation and Surfactants
}

DOI:

10.1021/acs.langmuir.9b03774

\section{Document Version}

Accepted author manuscript

Link to publication record in Manchester Research Explorer

\section{Citation for published version (APA):}

Liu, K., Yang, L., Peng, X., Wang, J., Lu, J. R., \& Xu, H. (2020). Modulation of Antimicrobial Peptide Conformation and Aggregation by Terminal Lipidation and Surfactants. Langmuir, 36(7), 1737-1744.

https://doi.org/10.1021/acs.langmuir.9b03774

\section{Published in:}

Langmuir

\section{Citing this paper}

Please note that where the full-text provided on Manchester Research Explorer is the Author Accepted Manuscript or Proof version this may differ from the final Published version. If citing, it is advised that you check and use the publisher's definitive version.

\section{General rights}

Copyright and moral rights for the publications made accessible in the Research Explorer are retained by the authors and/or other copyright owners and it is a condition of accessing publications that users recognise and abide by the legal requirements associated with these rights.

\section{Takedown policy}

If you believe that this document breaches copyright please refer to the University of Manchester's Takedown Procedures [http://man.ac.uk/04Y6Bo] or contact uml.scholarlycommunications@manchester.ac.uk providing relevant details, so we can investigate your claim.

\section{OPEN ACCESS}




\title{
Modulation of Antimicrobial Peptide Conformation and Aggregation by Terminal Lipidation and Surfactants
}

\author{
Kang Liu ${ }^{1}$, Liuxin Yang ${ }^{1}$, Xiaoting Peng ${ }^{1}$, Jiqian Wang ${ }^{1, *}$, Jian Ren $\mathrm{Lu}^{2}$, Hai Xu ${ }^{1, *}$ \\ ${ }^{1}$ State Key Laboratory of Heavy Oil Processing \& Centre for Bioengineering and \\ Biotechnology, China University of Petroleum (East China), Qingdao, 266580, China \\ ${ }^{2}$ Biological Physics Group, School of Physics and Astronomy, University of Manchester, \\ Oxford Road, Manchester M13 9PL, UK
}

Corresponding authors: Jiqian Wang, jqwang@upc.edu.cn

Hai Xu, xuh@upc.edu.cn 


\section{ABSTRACT}

The function and properties of peptide-based materials depend not only on the amino acid sequence but also the molecular conformations. In this paper, we chose a series of peptides $\mathrm{G}_{\mathrm{m}}(\mathrm{XXKK})_{\mathrm{n}} \mathrm{X}-\mathrm{NH}_{2}(\mathrm{~m}=0,3 ; \mathrm{n}=2,3 ; \mathrm{X}=\mathrm{I}, \mathrm{L}$, and $\mathrm{V})$ as the model molecules, and studied the conformation regulation through $\mathrm{N}$ terminus lipidation and their formulation with surfactants. The structural and morphological transition of peptide self-assemblies have also been investigated via transmission electron microscopy (TEM), atomic force microscopy (AFM), circular dichroism spectroscopy (CD), and small angle neutron scattering (SANS). With the terminal alkylation, the molecular conformation changed from random coil to $\beta$-sheet or $\alpha$-helix. The antimicrobial activities of alkylated peptide were different. $\mathrm{C}_{16}-\mathrm{G}_{3}(\mathrm{IIKK})_{3} \mathrm{I}-\mathrm{NH}_{2}$ showed antimicrobial activity against Streptococcus mutans while $\mathrm{C}_{16}-(\mathrm{IIKK})_{2} \mathrm{I}-\mathrm{NH}_{2}$ and $\mathrm{C}_{16}-\mathrm{G}_{3}(\mathrm{IIKK})_{2} \mathrm{I}-\mathrm{NH}_{2}$ didn't kill the bacteria. Surfactant sodium dodecyl sulfonate (SDS) could rapidly induce the self-assemblies of alkylated peptides $\left(\mathrm{C}_{16}-(\mathrm{IIKK})_{2} \mathrm{I}-\mathrm{NH}_{2}, \mathrm{C}_{16}-\mathrm{G}_{3}(\mathrm{IIKK})_{2} \mathrm{I}-\mathrm{NH}_{2}, \mathrm{C}_{16}-\mathrm{G}_{3}(\mathrm{VVKK})_{2} \mathrm{~V}-\mathrm{NH}_{2}\right)$ from nanofibers to micelles, along with the conformation changing from $\beta$-sheet to $\alpha$-helix. Cationic surfactant hexadecyl trimethyl ammonium bromide (CTAB) made the lipopeptide nanofibers thinner, and nonionic surfactant polyoxyethylene (23) lauryl ether $\left(\mathrm{C}_{12} \mathrm{EO}_{23}\right)$ induced the nanofibers much more intensive. Both the activity and conformation of $\alpha$ helical peptide could be modulated by lipidation. Then the self-assembled morphologies of alkylated peptides could also be further regulated with surfactants through hydrophobic, electrostatic and hydrogen bonding interactions. These 
results provided useful strategies to regulate the molecular conformations in peptide-based material functionalization.

\section{INTRODUCTION}

Short peptide motifs play critical roles in many biological functions, such as recognition, binding, signal transduction, catalysis, cell adhesion, movement, growth and even apoptosis, as well as body defensing and protection. It has been widely perceived that their biological activities not only rely on their primary amino acid sequences but also are closely related to the $2 \mathrm{D}$ and $3 \mathrm{D}$ structures they reside. ${ }^{1-3}$ For instance, the folding into helical conformations facilitate the YPWM peptides, derived from the HOX homeodomain protein, to bind the PBX homeodomain. ${ }^{4,5}$ For another instance, amphipathic $\alpha$-helical or $\beta$-sheet conformations are required for many antibacterial peptides to achieve effective membrane permeabilization. ${ }^{6,7}$ However, short peptide sequences usually tend to take disordered structures on their own. In vivo, it is usually large proteins that act as a scaffold and endow the resident short sequences with ordered patterns or folded structures.

To increase the folding ability of short peptides in solution for creating protein-like architectures, a simple and straightforward approach is acylation with long-chain fatty acids, i.e. lipidation, which usually occurs on either the N-terminal amine or the side chain amine of lysine or the side chain thiol of cysteine. ${ }^{8-14}$ Lipidation of peptides and proteins has been observed to not only induce or stabilize their secondary structures but also promote their self-association or association with cell membranes. As a result, some 
of their biological activities can be modified. For instance, lipidation of glucagon and its analogs with long-chain saturated fatty acids have been found to increase and balance their in intro potencies for the glucagon and glucagon-like peptide 1 receptors. ${ }^{8}$ Another typical example is that some inactive ultrashort sequences such as KKK can be endowed with antibacterial and antifungal activities. ${ }^{15,16}$ Simultaneously, due to their self-association induced by lipidation, some important physicochemical properties can be enhanced, including structural thermal stability, rheology, and resistance to enzymatic degradation. These enhancements are virtually favorable for their practical applications. Stupp and co-workers have designed a series of $\mathrm{N}$-terminally acylated peptides, termed as peptide amphiphiles (PAs), which can self-assemble into hydrogels. ${ }^{17-20}$ These PAs hydrogels have shown application potential in regenerative medicine.

Despite these advantageous effects, it is still challenging to predict what secondary structures are induced by lipidation based on certain sequences, as well as to establish the relationship among the secondary structures, supramolecular nanostructures, physicochemical properties, and biological functions of lipidated peptides and proteins. We have recently designed a series of peptides containing simple repeated IIKK sequences, G(IIKK) ${ }_{n} \mathrm{I}-\mathrm{NH}_{2}$ (n=2-4, G-Gly, I- Ile, and K-Lys), which are unstructured in water but fold into amphipathic $\alpha$-helical conformation in the bacterial membrane-mimicking environment. ${ }^{21}$ Furthermore, these peptides show potent antibacterial and anticancer activities. ${ }^{21-23}$ Considering that the hydrophobic $\beta$-branched Ile residue has high propensity for $\beta$-sheet structuring in protein folding, ${ }^{24}$ we reason that 
the biologically active $\mathrm{G}(\mathrm{IIKK})_{n} \mathrm{I}-\mathrm{NH}_{2}(\mathrm{n}=2-4)$ peptides may act an ideal peptide model for lipidation to achieve distinct secondary structures and activities. In this study, we conjugate palmitic acid to the N-terminus of $(\mathrm{IIKK})_{n} \mathrm{I}-\mathrm{NH}_{2}(\mathrm{n}=2-3)$ peptides and their analogues, $(\mathrm{LLKK})_{2} \mathrm{~L}-\mathrm{NH}_{2}$ and $(\mathrm{VVKK})_{2} \mathrm{~V}-\mathrm{NH}_{2}$ (L-leucine or Leu and V-valine or Val), giving rise to a series lipidated peptides, including $\mathrm{C}_{16}$-(IIKK) $)_{2} \mathrm{I}-\mathrm{NH}_{2}$, $\mathrm{C}_{16}-\mathrm{G}_{3}(\mathrm{IIKK})_{2} \mathrm{I}-\mathrm{NH}_{2}, \quad \mathrm{C}_{16}-\mathrm{G}_{3}(\mathrm{IIKK})_{3} \mathrm{I}-\mathrm{NH}_{2}, \quad \mathrm{C}_{16}-\mathrm{G}_{3}(\mathrm{LLKK})_{2} \mathrm{~L}-\mathrm{NH}_{2}, \quad$ and $\mathrm{C}_{16}-\mathrm{G}_{3}(\mathrm{VVKK})_{2} \mathrm{~V}-\mathrm{NH}_{2}$ (Scheme 1). At first, their secondary and supramolecular structures are investigated. Then, to understand the structure-function relationship, their antibacterial activities are assessed. Finally, their structural and morphological responsiveness to addition of conventional surfactants (anionic, cationic, and non-ionic) is also observed.

(1)

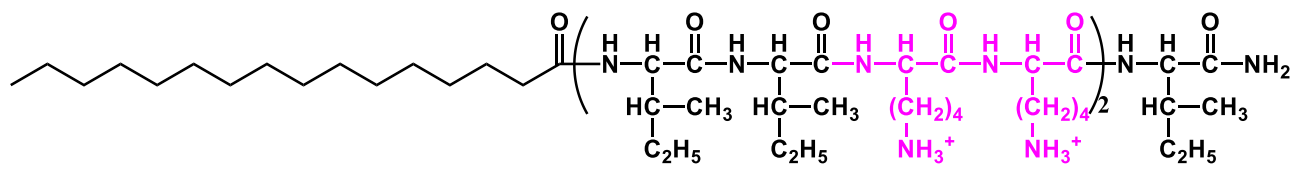

(2)

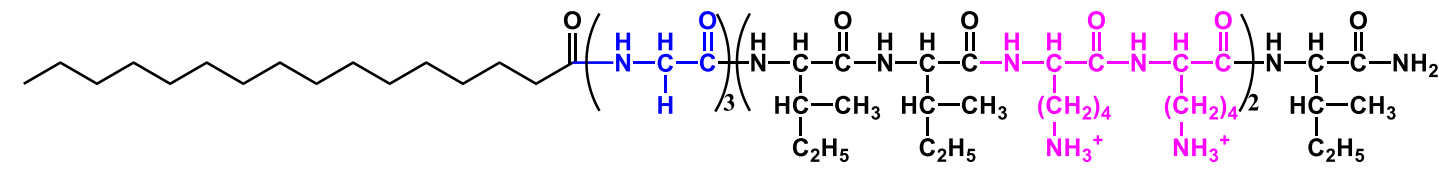

(3)

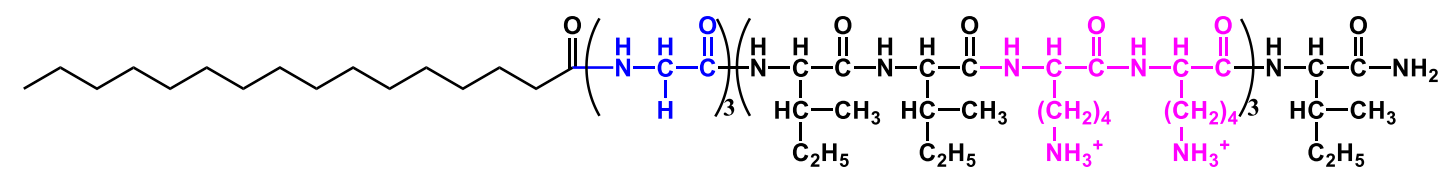

(4)

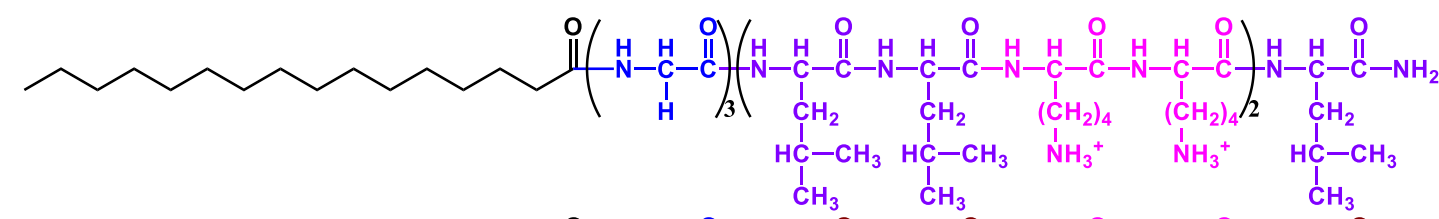

(5)

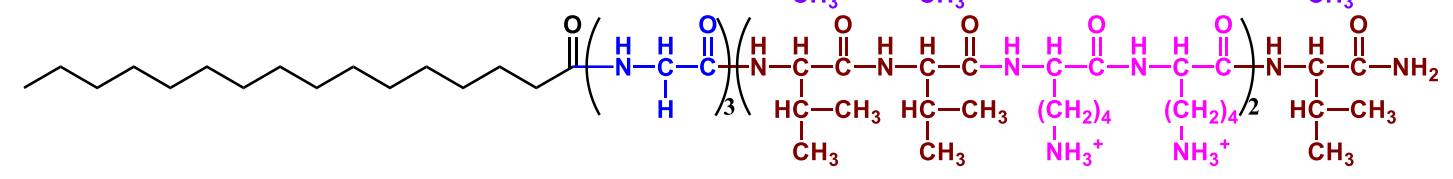

Scheme 1. Molecular structure of the lipidated peptides: (1) $\mathrm{C}_{16}$-(IIKK) ${ }_{2} \mathrm{I}-\mathrm{NH}_{2}$, (2) 
$\mathrm{C}_{16}-\mathrm{G}_{3}(\mathrm{IIKK})_{2} \mathrm{I}-\mathrm{NH}_{2}, \quad$ (3) $\mathrm{C}_{16}-\mathrm{G}_{3}(\mathrm{IIKK})_{3} \mathrm{I}-\mathrm{NH}_{2}, \quad$ (4) $\mathrm{C}_{16}-\mathrm{G}_{3}(\mathrm{LLKK})_{2} \mathrm{~L}-\mathrm{NH}_{2}$ and (5) $\mathrm{C}_{16}-\mathrm{G}_{3}(\mathrm{VVKK})_{2} \mathrm{~V}-\mathrm{NH}_{2}$.

\section{EXPERIMENTAL SECTION}

Materials and Chemicals. The peptide sequences were synthesized and lipidated on a CEM Liberty microwave synthesizer based on solid phase peptide synthesis (SPPS). The detailed procedures for synthesis and purification have been described in our previous works. ${ }^{25-26}$ The peptides were analyzed with reverse-phase high performance liquid chromatography (HPLC) and matrix-assisted laser desorption/ionization time-of-light mass spectrometry (MALDI-TOF MS) to confirm the purity. The results showed that the synthesized peptides were the target products with the purity of $>97 \%$ (Figure S1).

Sodium dodecyl sulfonate (SDS) was purchased from Sigma-Aldrich and Polyoxyethylene (23) lauryl ether $\left(\mathrm{C}_{12} \mathrm{EO}_{23}\right)$ was purchased from Acros Organics BVBA. These two surfactants were used without further purification. Hexadecyl trimethyl ammonium bromide (CTAB) was bought from Sinopharm Chemical Reagent Co., Ltd. and was recrystallized three times with acetone and ethanol before use. ${ }^{27}$ Solutions of surfactants, peptides and their mixtures of different mole ratios were prepared in water (Millipore, $\geq 18.2 \mathrm{M} \Omega \cdot \mathrm{cm}$ ). The $\mathrm{pH}$ of all the peptide solutions was adjusted to 7.0 with $0.1 \mathrm{mM} \mathrm{NaOH}$. And the solution $\mathrm{pH}$ was double checked before use.

Surface tension. Surface tension was measured with a KRÜSS Easy Dyne tensiometer using Wilhelm plate method at $25 \pm 0.1{ }^{\circ} \mathrm{C}$. The samples were kept for at least $60 \mathrm{~min}$ for equilibration before measurement. The measured surface tension had an accuracy of \pm 0.1 
$\mathrm{mN} \cdot \mathrm{m}^{-1}$

Circular dichroism (CD) spectroscopy. CD spectra of measurements were performed on a MOS-450 spectrometer (Biologic, France) at room temperature. Wavelength scans were recorded at $0.5 \mathrm{~nm}$ intervals from 190 to $270 \mathrm{~nm}$. A quartz cuvette with $0.05 \mathrm{~mm}$ path length was used in the measurements. After the solvent background was subtracted, the data were averaged based on 5 repeating measurements using Biokine software. The CD signals were expressed as $[\theta]\left(10^{3} \mathrm{deg} \cdot \mathrm{cm}^{2} \cdot \mathrm{dmol}^{-1}\right)$ versus wavelength.

Fluorescence spectroscopy. The fluorescence spectrum was collected on a Horiba Jobin Yvon Fluoromax-4 spectrometer using a $3.0 \mathrm{~mm}$ path-length quartz cuvette at room temperature. The samples of peptide solutions were mixed with Thioflavin-T (ThT) and the concentration of ThT was fixed at $0.05 \mathrm{mM}$. The excitation slits and emission slits were set as $2.0 \mathrm{~nm}$ and $3.0 \mathrm{~nm}$, respectively. The emission spectra were collected from $460 \mathrm{~nm}$ to $540 \mathrm{~nm}$ with the excitation wavelength at $442 \mathrm{~nm}$.

Morphology characterization of self-assemblies. The morphologies of lipidated peptide self-assemblies were characterized with transmission electron microscopy (TEM), cryogenic Transmission electron microscopy (Cryo-TEM) and atomic force microscopy (AFM). In TEM observation, a volume of $30 \mu \mathrm{L}$ solution was dropped on a piece of parafilm, and a 300-mesh copper grid coated with a carbon support film was putted onto the surface of the droplet. The extra sample solution was wicked away by filter paper after adsorption for $7 \mathrm{~min}$. Then, the grid was negatively stained with uranyl acetate $(2 \%$, w/v) aqueous solution for another $7 \mathrm{~min}$; and the excess aqueous solution was blotted 
with filter paper. TEM micrographs were recorded on a JEOL JEM-1400 Plus electron microscope with an accelerating voltage of $120 \mathrm{kV}$. The samples for Cryo-TEM characterization were prepared in a controlled environment vitrification system (CEVS). A volume of $2 \mu \mathrm{L}$ peptide solution was coated onto a TEM copper grid. And the grid was blotted with filter paper on both sides for about $6 \mathrm{~s}$ in order to form a solution thin film. Then the grid was plunged into a reservoir of liquid ethane (cooled by liquid nitrogen) at $-165^{\circ} \mathrm{C}$. The sample was stored in the liquid nitrogen until observation. The sample was examined at $-174^{\circ} \mathrm{C}$ on a JEOL JEM-1400 Plus TEM $(120 \mathrm{kV})$ after transferring the grid to a cryogenic sample holder (Gatan 626).

In AFM characterization, a volume of $20 \mu \mathrm{L}$ sample solution was dropped on a freshly cleaved mica sheet. After adsorption for $6 \mathrm{~min}$, the sample solution was dried by gently purging with $\mathrm{N}_{2}$. Images were imaged on a NanoScope IVa MultiMode Atomic Force Microscope (Digital Instruments, Santa Barbara, CA) with a tapping mode at a scan rate of $1.0 \mathrm{~Hz}$ and a scan angle of $0^{\circ}$. All images were flattened using NanoScope Analysis software with a second order line fit to correct for piezo-derived differences between scan lines.

Small angle neutron scattering (SANS). The SANS measurements were carried out on the LOQ diffractometer, ISIS Neutron Facility, Rutherford Appleton Laboratory (Oxford, UK). The sample solutions were prepared with $\mathrm{D}_{2} \mathrm{O}$, and the $\mathrm{pD}$ values were adjusted to 7.0 using $\mathrm{NaOD} \mathrm{D}_{2} \mathrm{O}$ solution. The samples were incubated under ambient conditions for 7 days before being transferred into a $2.0 \mathrm{~mm}$ path length disc-shaped fused silica cell for 
measurements. Incident neutron wavelengths were used ranging from 2.2 to $10.0 \AA$ at 25 Hz. The data fitting were performed using SansView program (ver. 4.2.0). A flexible cylinder elliptical model was used to fit the SANS profile.

Antimicrobial Activity and MTT assay. Streptococcus mutans was cultivated in LB media at $37{ }^{\circ} \mathrm{C}$ for $24 \mathrm{~h}$. Bacterial cells were separated and washed with PBS twice, and then suspended in the media again. A volume of $100 \mu \mathrm{L}$ bacterial suspension solution of $2 \times 10^{6} \mathrm{CFU} / \mathrm{mL}$ was added into $100 \mu \mathrm{L}$ lipidated peptide $\left(\mathrm{C}_{16}-(\mathrm{IIKK})_{2} \mathrm{I}-\mathrm{NH}_{2}\right.$, $\mathrm{C}_{16}-\mathrm{G}_{3}(\mathrm{IIKK})_{2} \mathrm{I}-\mathrm{NH}_{2}$ and $\left.\mathrm{C}_{16}-\mathrm{G}_{3}(\mathrm{IIKK})_{3} \mathrm{I}-\mathrm{NH}_{2}\right)$ solutions in a 96-well plate. The bacteria were incubated at $37^{\circ} \mathrm{C}$ for another $18 \mathrm{~h}$ and then $\mathrm{A}_{600}$ was measured using a microplate autoreader (Molecular Devices, M2e).

MTT assay was analyzed the effects of lipidated peptides on cytotoxicity of NIH 3T3 cells. Firstly, the NIH 3 T3 cells were seeded and incubated overnight in a 96 well plate at $37^{\circ} \mathrm{C}$. Then, the NIH $3 \mathrm{~T} 3$ cells were treated with certain concentration of lipidated peptides for $24 \mathrm{~h}$. Subsequently, adding $20 \mu \mathrm{L}$ ( $5 \mathrm{mg} / \mathrm{mL}$ ) MTT to each well and further incubated for $4 \mathrm{~h}$. Finally, the supernatant was removed and the precipitated formazan was dissolved with $150 \mu \mathrm{L}$ of dimethyl sulfoxide (DMSO) followed by measuring the absorbance at $490 \mathrm{~nm}$ (A490) on a microplate reader (Molecular Devices, M2e).

\section{RESULTS AND DISCUSSION}

Lipidation promotes conformational change and/or aggregation. Before lipidation, the peptides $\mathrm{G}(\mathrm{XXKK})_{2} \mathrm{X}-\mathrm{NH}_{2}$ or $(\mathrm{XXKK})_{2} \mathrm{X}-\mathrm{NH}_{2} \quad(\mathrm{X}=\mathrm{I}, \mathrm{L}$, and $\mathrm{V})$ tend to be unstructured in neutral water. ${ }^{23}$ After N-terminal acylation with palmitic acid, they show 
characteristic folding with distinct conformations. As shown in Figure 1a, $1.0 \mathrm{mM}$ $\mathrm{C}_{16}-(\mathrm{IIKK})_{2} \mathrm{I}-\mathrm{NH}_{2}, \mathrm{C}_{16}-\mathrm{G}_{3}(\mathrm{IIKK})_{2} \mathrm{I}-\mathrm{NH}_{2}$, and $\mathrm{C}_{16}-\mathrm{G}_{3}(\mathrm{VVKK})_{2} \mathrm{~V}-\mathrm{NH}_{2}$ display pronounced $\beta$-sheet characteristics, with a positive peak at $\sim 200 \mathrm{~nm}$ and a negative one at $\sim 218 \mathrm{~nm}$ in their CD spectra (Figure 1a). Compared with the former two lipidated peptides, $\mathrm{C}_{16}-\mathrm{G}_{3}(\mathrm{VVKK})_{2} \mathrm{~V}-\mathrm{NH}_{2}$ exhibits a marked reduction in the $\mathrm{CD}$ signal intensity at $\sim 218 \mathrm{~nm}$, presumably due to the decreased hydrophobicity of Val in comparison with Ile. The CD spectrum of $1.0 \mathrm{mM} \mathrm{C}_{16}-\mathrm{G}_{3}(\mathrm{LLKK})_{2} \mathrm{~L}-\mathrm{NH}_{2}$ is consistent with $\alpha$-helical conformations, as characterized by two negative peaks at $\sim 208$ and $\sim 222 \mathrm{~nm}$ (Figure 1a). These results are reminiscent of the propensities of the three amino acids for different secondary structures: $\beta$-branched hydrophobic Ile and Val favor $\beta$-sheet structuring while $\gamma$-branched Leu promotes helix formation. ${ }^{24,28}$ However, it is very interesting that $1.0 \mathrm{mM}$ $\mathrm{C}_{16}-\mathrm{G}_{3}(\mathrm{IIKK})_{3} \mathrm{I}-\mathrm{NH}_{2}$ exhibits a typical helical conformation (Figure 1a), indicating that increasing IIKK repeats or the peptide segment length can enhance the intramolecular hydrogen bonding (H-bonding) rather than the intermolecular one, thus facilitating helical conformations. These results suggest that the molecular conformation of lipidated peptides can be tuned by the sequence and length variations of their peptide segments. 

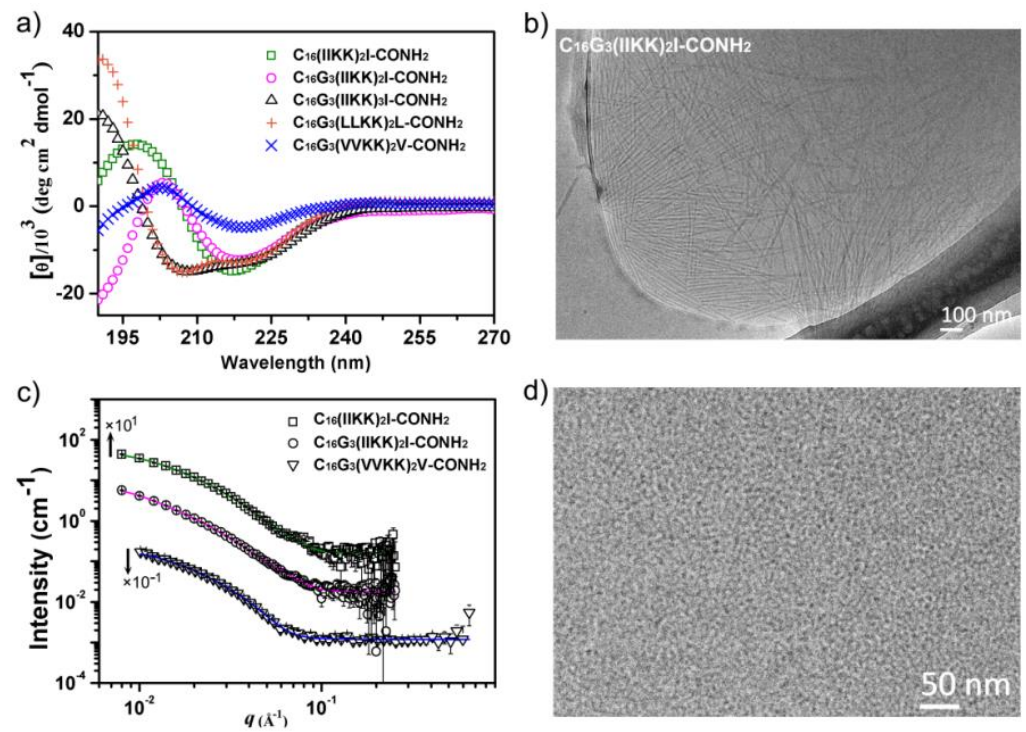

Figure 1. Structural characterizations of the designed lipidated peptides: (a) CD spectra, (b) cryo-TEM image of $\mathrm{C}_{16}-\mathrm{G}_{3}(\mathrm{IIKK})_{2} \mathrm{I}-\mathrm{NH}_{2}$ nanofibers, (c) SANS signal and fitted profiles of $\mathrm{C}_{16}-(\mathrm{IIKK})_{2} \mathrm{I}-\mathrm{NH}_{2}, \mathrm{C}_{16}-\mathrm{G}_{3}(\mathrm{IIKK})_{2} \mathrm{I}-\mathrm{NH}_{2}$, and $\mathrm{C}_{16}-\mathrm{G}_{3}(\mathrm{VVKK})_{2} \mathrm{~V}-\mathrm{NH}_{2}$ at a concentration of $1 \mathrm{mM}$, and (d) cryo-TEM image of $\mathrm{C}_{16}-\mathrm{G}_{3}(\mathrm{IIKK})_{3} \mathrm{I}-\mathrm{NH}_{2}$ micelles.

The lipidated peptides not only show well-defined secondary structures but also display enhanced surface activities. Surface tension measurements indicated that the five lipidated peptides have similar critical aggregation concentrations (CMCs) ( 0.5-1.0 $\mathrm{mM}$ ), with their surface tensions of $\sim 51 \mathrm{mN} / \mathrm{m}$ for $\mathrm{C}_{16}-\mathrm{G}_{3}(\mathrm{VVKK})_{2} \mathrm{~V}-\mathrm{NH}_{2}$ and $\sim 44$ $\mathrm{mN} / \mathrm{m}$ for the rest above the CMCs (Figure S2). Although the hydrophobic contacts between $\mathrm{C} 16$ alkyl chains are mainly responsible for their initial solution aggregation, their final aggregated morphology was found to be dictated by the interplay between this hydrophobic interaction and peptide folding. Cryogenic TEM (cryo-TEM) characterization revealed the formation of long nanofibers by the three $\beta$-sheet lipidated peptides $\left(\mathrm{C}_{16}-(\mathrm{IIKK})_{2} \mathrm{I}-\mathrm{NH}_{2}, \mathrm{C}_{16}-\mathrm{G}_{3}(\mathrm{IIKK})_{2} \mathrm{I}-\mathrm{NH}_{2}\right.$, and $\left.\mathrm{C}_{16}-\mathrm{G}_{3}(\mathrm{VVKK})_{2} \mathrm{~V}-\mathrm{NH}_{2}\right)$ at a 
concentration of $1 \mathrm{mM}$, as shown in Figure $1 \mathrm{~b}$ and Figure S3 (cryo-TEM images of $\mathrm{C}_{16-}(\mathrm{IIKK})_{2} \mathrm{I}-\mathrm{NH}_{2}$ and $\left.\mathrm{C}_{16}-\mathrm{G}_{3}(\mathrm{VVKK})_{2} \mathrm{~V}-\mathrm{NH}_{2}\right)$. At this concentration, similar neutron scattering profiles were observed in small angle neutron scattering (SANS) measurements (Figure 1c). Furthermore, a flexible cylindrical model (FCM) was found to well fit these SANS profiles, as denoted by the solid lines in Figure 1c. The key parameters from the data fitting are given in Table 1 . It can be seen that the three peptide nanofibers have thicknesses of $\sim 6-7 \mathrm{~nm}$ and widths of $\sim 13-19 \mathrm{~nm}$. The thicknesses are markedly larger than their molecular lengths in extended conformations $\left(\sim 4.8 \mathrm{~nm}\right.$ for $\mathrm{C}_{16}-(\mathrm{IIKK})_{2} \mathrm{I}-\mathrm{NH}_{2}$ and $\sim 5.8 \mathrm{~nm}$ for $\mathrm{C}_{16}-\mathrm{G}_{3}(\mathrm{IIKK})_{2} \mathrm{I}-\mathrm{NH}_{2}$ and $\left.\mathrm{C}_{16}-\mathrm{G}_{3}(\mathrm{VVKK})_{2} \mathrm{~V}-\mathrm{NH}_{2}\right)$, suggesting the formation of a significantly interdigitated bilayer. $^{29,30}$ We have also measured the nanofiber diameter of $\mathrm{C}_{16}-(\mathrm{IIKK})_{2} \mathrm{I}-\mathrm{NH}_{2}, \mathrm{C}_{16}-\mathrm{G}_{3}(\mathrm{IIKK})_{2} \mathrm{I}-\mathrm{NH}_{2}, \mathrm{C}_{16}-\mathrm{G}_{3}(\mathrm{VVKK})_{2} \mathrm{~V}-\mathrm{NH}_{2}$. Each lipidated peptide has been measured 100 times based on at least 5 TEM images. The statistics results were consistent with the SANS results. The widths of self-assembled peptide nanostructures can reflect the degree of lateral stacking of $\beta$-sheets along the $x$-direction. ${ }^{31,32}$ The $\mathrm{C}_{16}-\mathrm{G}_{3}(\mathrm{IIKK})_{2} \mathrm{I}-\mathrm{NH}_{2}$ nanofibers have larger widths than the $\mathrm{C}_{16}-\mathrm{G}_{3}(\mathrm{VVKK})_{2} \mathrm{~V}-\mathrm{NH}_{2}$ ones, well consistent with our recent observations that upon the substitution of Val for the Ile close to the C-terminal of $\mathrm{Ac}-\mathrm{KI}_{4} \mathrm{~K}-\mathrm{NH}_{2}$, the resulting Ac- $\mathrm{KI}_{3} \mathrm{VK}-\mathrm{NH}_{2}$ forms narrower nanotubes, with their widths decreasing from more than one hundred to $\sim 38$ nanometers. ${ }^{31}$ Given that the same $\beta$-branching geometry of Ile and Val side chains, these results reveal the important role of amino acid side-chain hydrophobic collapse in promoting the lateral packing of $\beta$-sheets. In fact, the nanofibers 
of lipidated peptides are akin to amyloid fibrils, as demonstrated by a marked enhancement in thioflavin $\mathrm{T}$ (ThT) fluorescence emission upon interacting with them (Figure S4).

In contrast, only spherical micelles with diameters of $\sim 3-4 \mathrm{~nm}$ were observed for $\mathrm{C}_{16}-\mathrm{G}_{3}(\mathrm{IIKK})_{3} \mathrm{I}-\mathrm{NH}_{2}$ and $\mathrm{C}_{16}-\mathrm{G}_{3}(\mathrm{LLKK})_{2} \mathrm{~L}-\mathrm{NH}_{2}$ at a concentration of 1 or $4 \mathrm{mM}$ (Figure 1d and Figure S5). Such an observation is consistent with their structural features, i.e. $\alpha$-helical conformations (intramolecular H-bonding, Figure 1a) and little enhancement in ThT fluorescence upon interacting with the peptide aggregates (Figure S4).

Taken together, it is the $\beta$-sheet $\mathrm{H}$-bonding interaction between peptide backbones that prompts the axial aggregation of lipidated peptide molecules (denoted as the $y$-direction), and then the lateral stacking of $\beta$-sheets primarily arises from the close contact of hydrophobic amino acid side chains (denoted as the $x$-direction). Such a hierarchical self-assembly process has been extensively observed for many designed peptides that can form 1D nanostructures, such as nanofibers, wide nanoribbons, and nanotubes. ${ }^{29,31-33}$ On the other hand, due to the inherent chirality of amino acids, peptide $\beta$-sheets tend to twist. $^{33,34}$ The natural twisting of $\beta$-sheets, together with the repulsive interaction among Lys side chains, limits their lateral stacking to a certain degree, eventually leading to nanofibers with twisting marks, as indicated by AFM imaging (Figure S6).

Table 1 The best fitting results of the SANS data of $\mathrm{C}_{16}-(\mathrm{IIKK})_{2} \mathrm{I}-\mathrm{NH}_{2}$, $\mathrm{C}_{16}-\mathrm{G}_{3}(\mathrm{IIKK})_{2} \mathrm{I}-\mathrm{NH}_{2}$ and $\mathrm{C}_{16}-\mathrm{G}_{3}(\mathrm{VVKK})_{2} \mathrm{~V}-\mathrm{NH}_{2}{ }^{\mathrm{c})}$ 


\begin{tabular}{lccc}
\hline Peptides & $\mathrm{C}_{16}(\mathrm{IIKK})_{2} \mathrm{I}-\mathrm{CONH}_{2}$ & $\mathrm{C}_{16} \mathrm{G}_{3}(\mathrm{IIKK})_{2} \mathrm{I}-\mathrm{CONH}_{2}$ & $\mathrm{C}_{16} \mathrm{G}_{3}(\mathrm{VVKK})_{2} \mathrm{~V}-\mathrm{CONH}{ }_{2}$ \\
\hline Fitting model & $\mathrm{FCM}^{\mathrm{a})}$ & $\mathrm{FCM}$ & $\mathrm{FCM}$ \\
Effective Volume Fraction (\%) & 0.065 & 0.066 & 0.032 \\
Background & 0.016 & 0.018 & 0.012 \\
Length $(\AA)$ & $>1000$ & $>1000$ & $>1000$ \\
Kuhn_Length $(\AA)$ & 100 & 250 & 64 \\
p1_Radius $(\AA)$ & 29.2 & 31.1 & 36.7 \\
Axis_ratio & 2.52 & 3.07 & 1.78 \\
Sld_Cyl $\left(\times 10^{-6} \AA^{-2}\right)^{\text {b) }}$ & 4.0 & 4.0 & 4.0 \\
Sld_Sol $\left(\times 10^{-6} \AA^{-2}\right)^{\text {b) }}$ & 6.35 & 6.35 & 6.35 \\
$\chi^{2} / N_{\text {pts }}$ & 1.04 & 0.82 & 0.58 \\
\hline
\end{tabular}

a) FCM denotes the flexible cylinder model. ${ }^{\text {b) }}$ Sld_Cyl and SLD_Sol are the scattering length density $(\rho)$ of scattering entities (cylinders) and the solvent $\left(\mathrm{D}_{2} \mathrm{O}\right)$, respectively. ${ }^{\mathrm{c})}$ The fitting was performed in the presence of size polydispersity for the radius and Kuhn length of the long and thick nanofibers.

The effect of lipidation on biological activities. Antibacterial activities of three lipidated peptides against Streptococcus mutans (S. mutans) were investigated by using the standard microdilution method. The lipidated peptide $\mathrm{C}_{16}-\mathrm{G}_{3}(\mathrm{IIKK})_{3} \mathrm{I}-\mathrm{NH}_{2}$ showed good antimicrobial activity which is similar to that of $\mathrm{G}(\mathrm{IIKK})_{3} \mathrm{I}-\mathrm{NH}_{2}$. The MIC values of $\mathrm{G}(\mathrm{IIKK})_{3} \mathrm{I}-\mathrm{NH}_{2}$ to $E$. coli and B. subtilis were 8.0 and $2.0 \mu \mathrm{M}$, respectively. ${ }^{21-23,35-37}$ While the other two lipidated peptides, $\mathrm{C}_{16^{-}}(\mathrm{IIKK})_{2} \mathrm{I}-\mathrm{NH}_{2}$ and $\mathrm{C}_{16}-\mathrm{G}_{3}(\mathrm{IIKK})_{2} \mathrm{I}-\mathrm{NH}_{2}$, had no antimicrobial activities (Figure 2a). The three lipidated peptides had no adverse effect of the cytotoxicity toward the model host mammalian cells (NIH 3T3) (Figure 2b). 

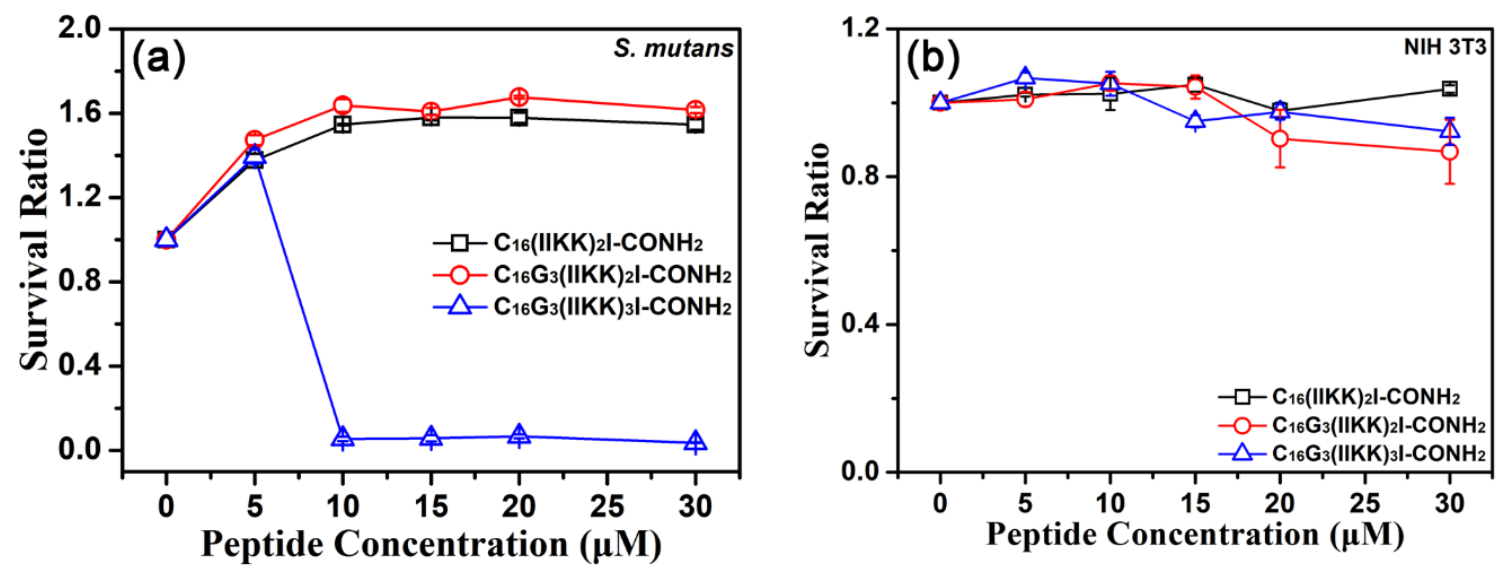

Figure 2. Antibacterial ability and cytotoxicity of the designed lapidated peptides. (a) antimicrobial activity of lipidated peptides, (b) cytotoxicity of lipidated peptides.

As we all known, self-assembly is deleterious to their antibacterial potency. In the case of $\mathrm{C}_{16}-\mathrm{G}_{3}(\mathrm{IIKK})_{3} \mathrm{I}-\mathrm{NH}_{2}$, there is more strong intra-molecular interactions while weaker intermolecular interactions. $\mathrm{C}_{16}-\mathrm{G}_{3}(\mathrm{IIKK})_{3} \mathrm{I}-\mathrm{NH}_{2}$ showed antibacterial activity far below its $\mathrm{CMC}(10 \mu \mathrm{M})$ in monomer state, and the self-assembled lipopeptides (aggregates of molecules like micelles) were not as tightly bound, thereby gaining the ability to dis-aggregate upon interaction with bacteria and the ability to exert their antibacterial activity. For the lipidated peptides $\mathrm{C}_{16}-(\mathrm{IIKK})_{2} \mathrm{I}-\mathrm{NH}_{2}$ and $\mathrm{C}_{16}-\mathrm{G}_{3}(\mathrm{IIKK})_{2} \mathrm{I}-\mathrm{NH}_{2}$, the propensity for forming nanofibers that inhibited their antimicrobial activities. These two lipidated peptides had stronger intermolecular interactions which result in more molecules to format of long nanofibers while fewer molecules to interact with bacteria. Therefore, the antimicrobial activities of lipidated peptides that with $\alpha$-helical conformation is better than that with $\beta$-sheet conformation when the use concentration is above their CMC. 
In our previous work, $\mathrm{G}(\mathrm{IIKK})_{2} \mathrm{I}-\mathrm{NH}_{2}$ had antimicrobial activities against to $E$. coli and B. subtilis with MICs in the range of $30-125 \mu \mathrm{M}^{21}$ After lipidation, the peptide $\mathrm{C}_{16}-\mathrm{G}_{3}(\mathrm{IIKK})_{2} \mathrm{I}-\mathrm{NH}_{2}$ showed no antimicrobial activity. Therefore, the antimicrobial activity of peptides could be regulated by the lipidation of $\mathrm{N}$-terminus and the length of their peptide segments. The active peptide sequences of these lipidated peptides could be released by enzymatic cleavage. This is of great significance for biological application.

Anionic SDS-induced conformational transition from $\beta$-sheets to $\alpha$-helices and disassembly of aggregated nanofibers. The effects of SDS on conformational and self-assembly morphologies transition for the lipidated peptides $\mathrm{C}_{16}-(\mathrm{IIKK})_{2} \mathrm{I}-\mathrm{NH}_{2}$ and $\mathrm{C}_{16}-\mathrm{G}_{3}(\mathrm{IIKK})_{2} \mathrm{I}-\mathrm{NH}_{2}$ were investigated by $\mathrm{CD}$ and Cryo-TEM. As shown in Figure 3a, the secondary structure of $\mathrm{C}_{16}-(\mathrm{IIKK})_{2} \mathrm{I}-\mathrm{NH}_{2}$ adopted $\beta$-sheet conformation while in 8 $\mathrm{mM}$ and $16 \mathrm{mM}$ SDS solutions, but adopted $\alpha$-helical conformation in $64 \mathrm{mM}$ SDS solution. And $\mathrm{C}_{16}-\mathrm{G}_{3}(\mathrm{IIKK})_{2} \mathrm{I}-\mathrm{NH}_{2}$ adopted $\beta$-sheet conformation in $8 \mathrm{mM}$ SDS solution, while adopted $\alpha$-helical conformation in $16 \mathrm{mM}$ and $64 \mathrm{mM}$ SDS solutions. All these results indicated that increasing the peptide segment length (GGG) could decrease the intermolecular hydrogen bonding and increase the intramolecular hydrogen bonding. And the anionic surfactant SDS could disrupt the intermolecular bonding of cationic lipidated peptides and therefore change their secondary structure and morphologies. This is due to the stronger electrostatic attraction between lipidated peptides and SDS molecules. The results found in CD spectra were in agreement with that found in Cryo-TEM. When the concentration of SDS was fixed at $8 \mathrm{mM}$, nanofibers were the dominated morphologies 
(Figure 3b). When the concentration of SDS was further increased, the Cryo-TEM images revealed that SDS could obviously disrupt the nanofiber structures of lipidated peptides (16 mM SDS). The nanofibers of lipidated peptides were decreased and the micelles appeared in this condition. When the SDS concentration was raised to $64 \mathrm{mM}$, the nanofibers disappeared, leaving only micelles in the solution. The results of $\mathrm{C}_{16}-\mathrm{G}_{3}(\mathrm{VVKK})_{2} \mathrm{I}-\mathrm{NH}_{2}$ with SDS were similar to those of $\mathrm{C}_{16}-(\mathrm{IIKK})_{2} \mathrm{I}-\mathrm{NH}_{2}$ and $\mathrm{C}_{16}-\mathrm{G}_{3}(\mathrm{IIKK})_{2} \mathrm{I}-\mathrm{NH}_{2}$ (Figure S3). 

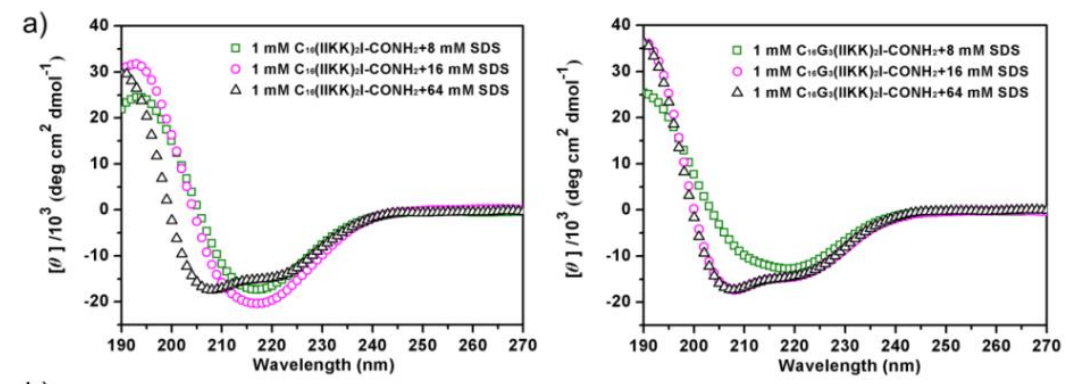

b)
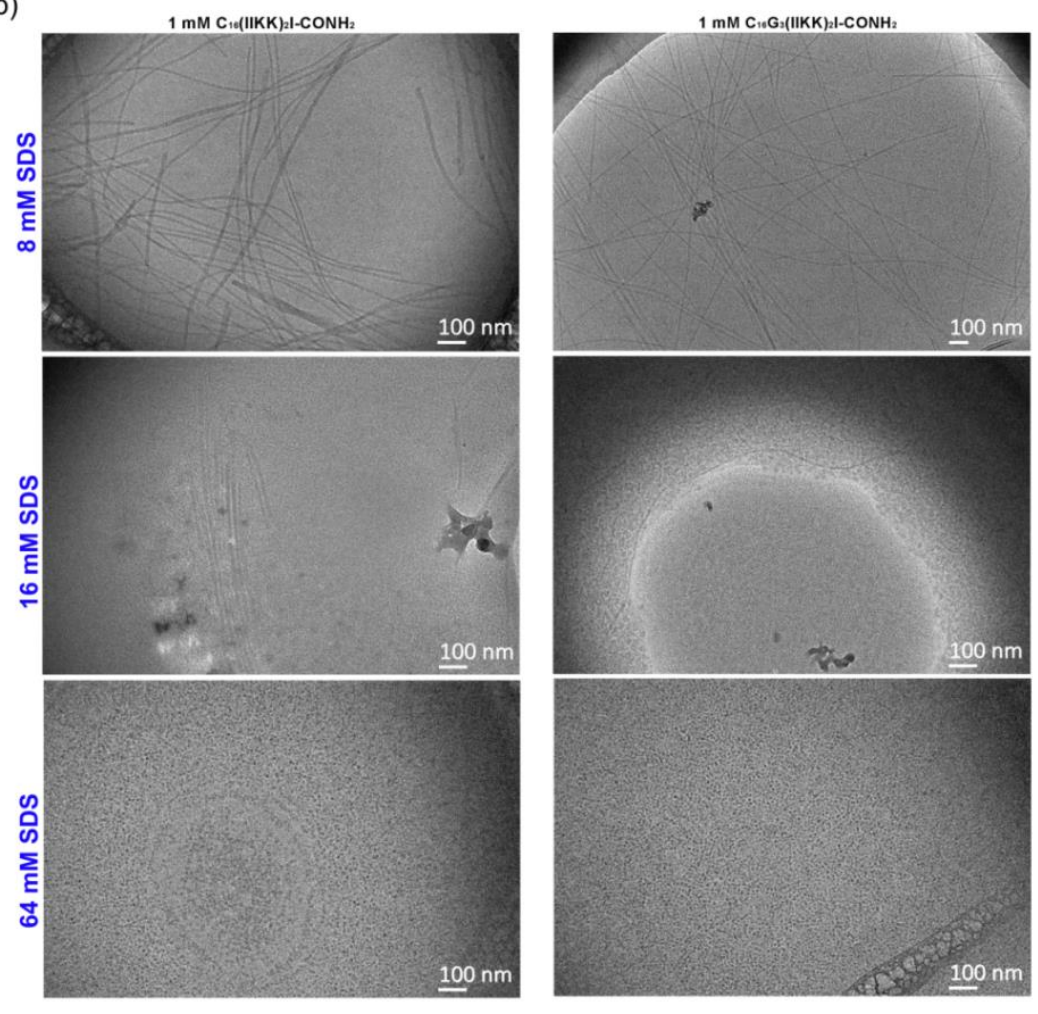

Figure 3. (a) $\mathrm{CD}$ spectra and (b) cryo-TEM images of $1 \mathrm{mM} \mathrm{C}$ C6- $^{-}(\mathrm{IIKK})_{2} \mathrm{I}-\mathrm{NH}_{2}$ and $\mathrm{C}_{16}-\mathrm{G}_{3}(\mathrm{IIKK})_{2} \mathrm{I}-\mathrm{NH}_{2}$ with different concentrations of SDS ( $8 \mathrm{mM}, 16 \mathrm{mM}$ and $\left.64 \mathrm{mM}\right)$.

Based on the results above, the possible mechanism of the interaction between lipidated peptides $\left(\mathrm{C}_{16}-(\mathrm{IIKK})_{2} \mathrm{I}-\mathrm{NH}_{2}\right.$ and $\left.\mathrm{C}_{16}-\mathrm{G}_{3}(\mathrm{IIKK})_{2} \mathrm{I}-\mathrm{NH}_{2}\right)$ and $\mathrm{SDS}$ is supported by two steps: (i) the nanofibers were disrupted due to the insertion of SDS into nanosheets of lipidated via electrostatic attraction between the hydrophilic moieties of peptide and SDS and (ii) the micelles formation by peptide and surfactant molecules through electrostatic force 
together with hydrophobic interaction.

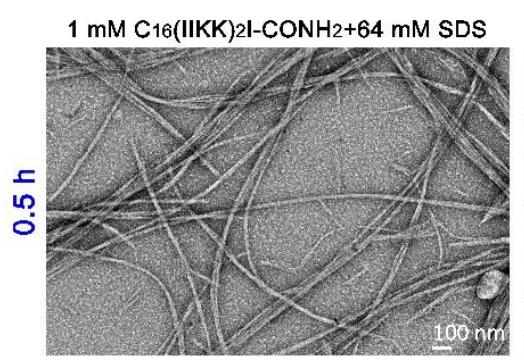

$1 \mathrm{mM} \mathrm{C} 16 \mathrm{G}_{3}(\mathrm{IIKK}) 2 \mathrm{l}-\mathrm{CONH}_{2}+64 \mathrm{mM}$ SDS
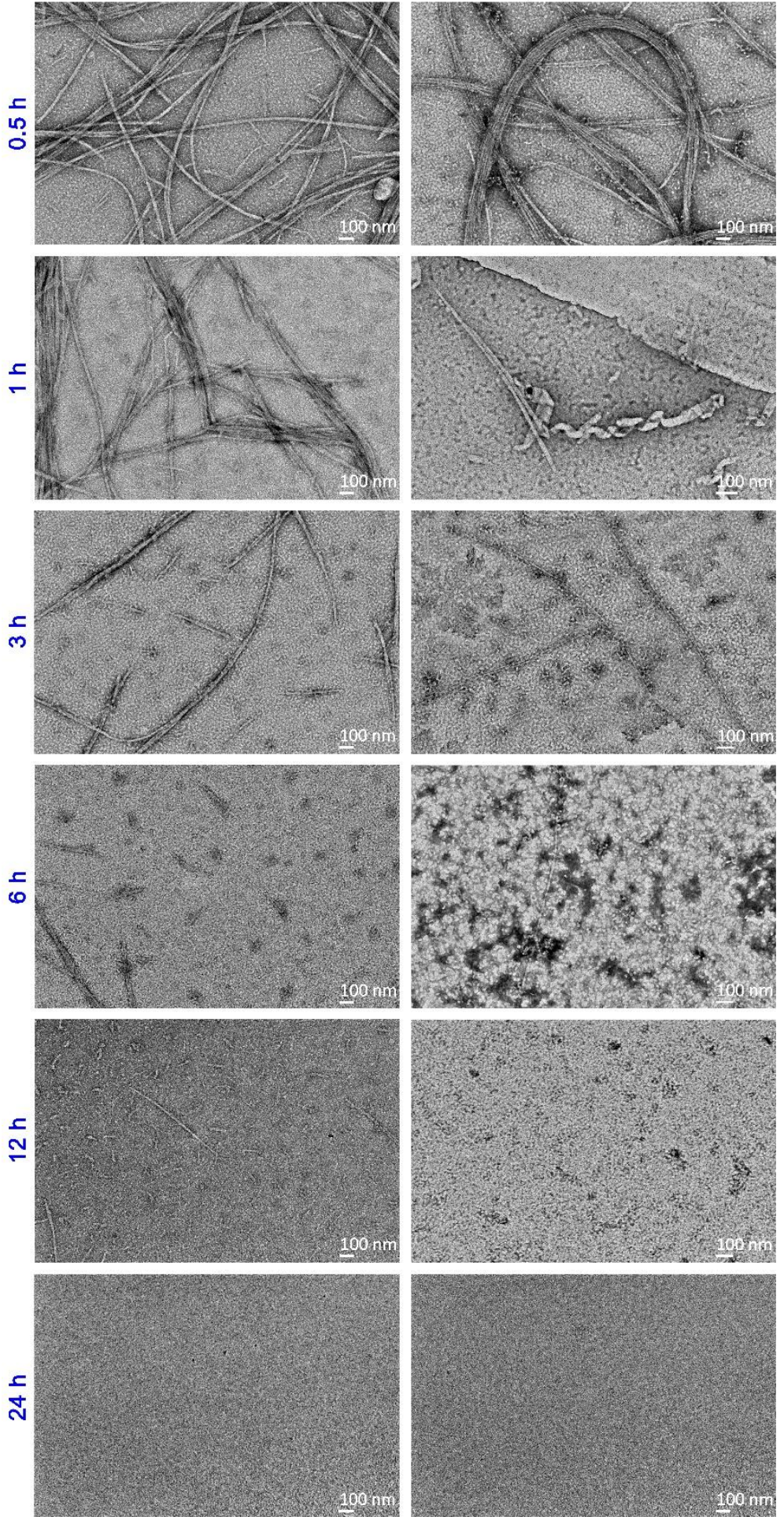

Figure 4. Time-dependent TEM images of $1 \mathrm{mM}^{\mathrm{C}_{16}-(\mathrm{IIKK})_{2} \mathrm{I}-\mathrm{NH}_{2}}$ and 
$\mathrm{C}_{16}-\mathrm{G}_{3}(\mathrm{IIKK})_{2} \mathrm{I}-\mathrm{NH}_{2}$ with $64 \mathrm{mM}$ SDS. The samples were characterized at $0.5,1,3,6,12$ and $24 \mathrm{~h}$.

The nanofibers could be rapidly disaggregated with the addition of surfactant of opposite charges (Figure 4). We can see that fibril bundles were formed by the parallel packing of nanofibers at $0.5 \mathrm{~h}$ for both two lipidated peptides. This is due to the SDS molecules binding to amino group of Lys side chains that decreased the electrostatic repulsion between nanosheets. And then nanofibers were aggregated together through hydrophobic interaction. With the time increased (1, 3, 6 and $12 \mathrm{~h})$, more and more SDS molecules could insert into nanosheets which result in the disruption of nanofibers. Finally, the formation of micelles by peptide and SDS molecules were taken in $24 \mathrm{~h}$. This indicated that the disruption of nanofibers and reconstruction of micelles were rather quick, which may favor their bactericidal behaviors. Furthermore, the time-dependent morphology transition phenomena might be used in stimuli responsive peptide-based biomaterial development, especially in personal care products with surfactants.

The influence of cationic and non-ionic surfactants. In order to investigate the influence of other types of surfactants on the morphologies transition of lipidated peptides, a cationic surfactant $\mathrm{CTAB}$ and a nonionic surfactant $\mathrm{C}_{12} \mathrm{EO}_{23}$ were used instead of SDS. As shown in Figure 5a and Figure 5b, when adding $8 \mathrm{mM} \mathrm{CTAB}$, the nanofibers of $\mathrm{C}_{16}-(\mathrm{IIKK})_{2} \mathrm{I}-\mathrm{NH}_{2}$ and $\mathrm{C}_{16}-\mathrm{G}_{3}(\mathrm{IIKK})_{2} \mathrm{I}-\mathrm{NH}_{2}$ became thinner $(\sim 7 \mathrm{~nm})$ compared to their original state. And the micelles with diameters $\sim 3-4 \mathrm{~nm}$ were also observed. It was indicated that the electrostatic repulsion between $\mathrm{CTAB}$ and peptide molecules that 
compressed the width of the nanofibers. The original nanofibers morphologies of lipidated peptides did not change with the addition of $2.5 \mathrm{mM} \mathrm{C}_{12} \mathrm{EO}_{23}$. But the density of nanofibers increased. This was due to the formation of intermolecular hydrogen bonding between the hydrophilic moiety of $\mathrm{C}_{12} \mathrm{EO}_{23}$ and peptide segment. $\mathrm{CD}$ spectra of $1 \mathrm{mM}$ $\mathrm{C}_{16}-(\mathrm{IIKK})_{2} \mathrm{I}-\mathrm{NH}_{2}$ and $\mathrm{C}_{16}-\mathrm{G}_{3}(\mathrm{IIKK})_{2} \mathrm{I}-\mathrm{NH}_{2}$ with both $\mathrm{CTAB}$ and $\mathrm{C}_{12} \mathrm{EO}_{23}$ still exhibited a positive peak at $\sim 198 \mathrm{~nm}$ and a negative one at $\sim 218 \mathrm{~nm}$ (Figure S7), indicating the $\beta$-sheet secondary structures. ${ }^{38}$ Combined with the effect of SDS on lipidated peptides, it indicated that the conformational and self-assembly morphologies transition of peptides could be modulate by changing electrostatic interaction and hydrophobic interaction, as well as the concentration of surfactants.

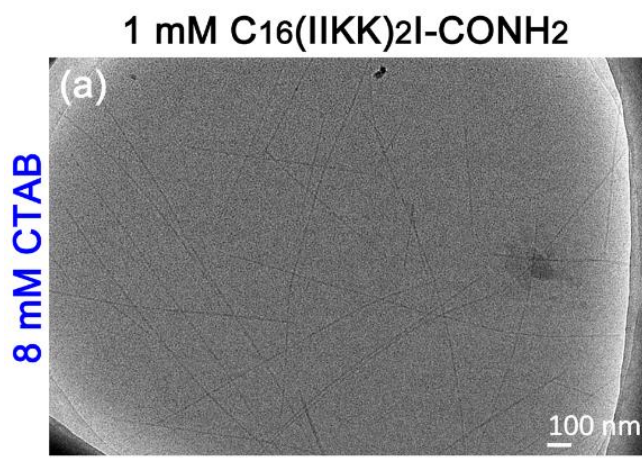

$1 \mathrm{mM} \mathrm{C} 16 \mathrm{G} 3(\mathrm{IIKK}) 2 \mathrm{I}-\mathrm{CONH} 2$
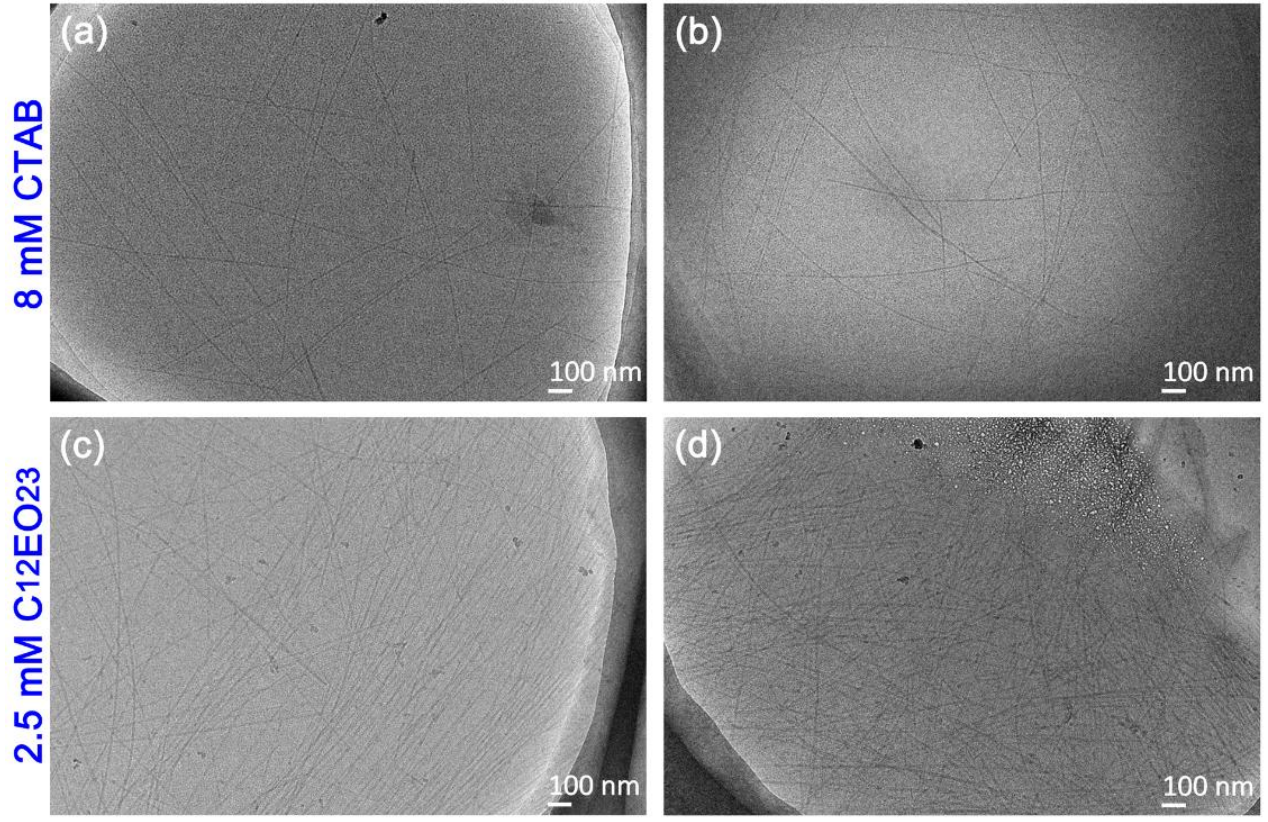

Figure 5. cryo-TEM images of $1 \mathrm{mM} \mathrm{C}_{16}-(\mathrm{IIKK})_{2} \mathrm{I}-\mathrm{NH}_{2}$ and $\mathrm{C}_{16}-\mathrm{G}_{3}(\mathrm{IIKK})_{2} \mathrm{I}-\mathrm{NH}_{2}$ with $8 \mathrm{mM} \mathrm{CTAB}$ and $2.5 \mathrm{mM} \mathrm{C}_{12} \mathrm{EO}_{23}$. (a) $1 \mathrm{mM} \mathrm{C}_{16}-(\mathrm{IIKK})_{2} \mathrm{I}-\mathrm{NH}_{2}$ with $8 \mathrm{mM} \mathrm{CTAB}$, (b) $1 \mathrm{mM} \mathrm{C}_{16}-\mathrm{G}_{3}(\mathrm{IIKK})_{2} \mathrm{I}-\mathrm{NH}_{2}$ 
with $8 \mathrm{mM} \mathrm{CTAB}$, (c) $1 \mathrm{mM} \mathrm{C}_{16}$-(IIKK) $)_{2} \mathrm{I}-\mathrm{NH}_{2}$ with $2.5 \mathrm{mM} \mathrm{C}_{12} \mathrm{EO}_{23}$, (d) $1 \mathrm{mM} \mathrm{C}_{16}-\mathrm{G}_{3}(\mathrm{IIKK})_{2} \mathrm{I}-\mathrm{NH}_{2}$ with $2.5 \mathrm{mM} \mathrm{C}_{12} \mathrm{EO}_{23}$.

\section{CONCLUSIONS}

We have shown that the influence of N-terminal lipidation on the conformation and aggregation of $\alpha$-helical antimicrobial peptide. Meanwhile, the interaction between lipidated peptides and surfactants were also demonstrated. The lipidation enhanced the hydrophobic interaction and induced the formation of $\beta$-sheet or $\alpha$-helix conformation along with hydrogen bonding and electrostatic interactions in the peptide segments. Anionic surfactant SDS could affect the secondary structure and morphology of positively charged lipidated peptides. The addition of cationic and nonionic surfactants only give rise to changes of width and number of nanofibers. The essence of these conformational and morphological transition is the mutual conversion between the driving forces of electrostatic, hydrophobic and hydrogen bonding interactions. These results help us to understand the regularity of self-assembly behavior of lipidated peptides in the presence of surfactant and provide a new pathway for the development of antimicrobial peptides.

\section{ASSOCIATED CONTENT}

\section{Supporting Information}

The Supporting Information is available free of charge on the ACS Publications website. Content: HPLC and MS spectra of lipidated peptides; surface tension profiles of designed 
lipidated peptides; cryo-TEM images of $\mathrm{C}_{16}-(\mathrm{IIKK})_{2} \mathrm{I}-\mathrm{NH}_{2}, \mathrm{C}_{16}-\mathrm{G}_{3}(\mathrm{VVKK})_{2} \mathrm{~V}-\mathrm{NH}_{2}$, and $\mathrm{C}_{16}-\mathrm{G}_{3}(\mathrm{VVKK})_{2} \mathrm{~V}-\mathrm{NH}_{2}$ with $64 \mathrm{mM}$ SDS; fluorescence emission spectra of ThT with $\mathrm{C}_{16}-\mathrm{G}_{3}(\mathrm{IIKK})_{2} \mathrm{I}-\mathrm{NH}_{2}$ and $\mathrm{C}_{16}-\mathrm{G}_{3}(\mathrm{IIKK})_{3} \mathrm{I}-\mathrm{NH}_{2}$; cryo-TEM images of $\mathrm{C}_{16}-\mathrm{G}_{3}(\mathrm{IIKK})_{3} \mathrm{I}-\mathrm{NH}_{2}$, $\mathrm{C}_{16^{-}}-\mathrm{G}_{3}(\mathrm{LLKK})_{2} \mathrm{~L}-\mathrm{NH}_{2}$ and $\mathrm{C}_{16^{-}} \mathrm{G}_{3}(\mathrm{LLKK})_{2} \mathrm{~L}-\mathrm{NH}_{2}$; AFM images of $\mathrm{C}_{16^{-}}(\mathrm{IIKK})_{2} \mathrm{I}-\mathrm{NH}_{2}$, $\mathrm{C}_{16}-\mathrm{G}_{3}(\mathrm{IIKK})_{2} \mathrm{I}-\mathrm{NH}_{2}, \mathrm{C}_{16}-(\mathrm{VVKK})_{2} \mathrm{~V}-\mathrm{NH}_{2}$ and $\mathrm{C}_{16}-\mathrm{G}_{3}(\mathrm{VVKK})_{2} \mathrm{~V}-\mathrm{NH}_{2} ; \mathrm{CD}$ spectra of $\mathrm{C}_{16}-(\mathrm{IIKK})_{2} \mathrm{I}-\mathrm{NH}_{2}$ and $\mathrm{C}_{16}-\mathrm{G}_{3}(\mathrm{IIKK})_{2} \mathrm{I}-\mathrm{NH}_{2}$ with $\mathrm{CTAB}$ and $\mathrm{C}_{12} \mathrm{EO}_{23}$.

\section{AUTHOR INFORMATION}

\section{Corresponding Author}

*E-mail: jqwang@upc.edu.cn; xuh@upc.edu.cn

\section{Notes}

There are no conflicts to declare.

\section{ACKNOWLEDGEMENTS}

This work was supported by the National Natural Science Foundation of China (Grant Nos. 21573287, 21673293 and U1832108).

\section{REFERENCES}

(1) Liu, L.; Li, Q.; Zhang, S.; Wang, X.; Hoffmann, S. V.; Li, J.; Liu, Z.; Besenbacher, F.; Dong, M. Identification of a Novel Parallel $\beta$-Strand Conformation within Molecular Monolayer of Amyloid Peptide. Adv. Sci. 2016, 3, 1500369. 
(2) Liu, L.; Klausen, L. H.; Dong, M. Two-Dimensional Peptide Based Functional Nanomaterials. Nano Today 2018, 23, 40-58.

(3) Zhang, L.; Chen, Q.; Li, P.; Yuan, L.; Feng, Y.; Wang, J.; Mao, X.; Liu, L. Deformation of Stable and Toxic hIAPP Oligomers by Liposomes with Distinct Nanomechanical Features and Reduced Cytotoxicity. Chem. Commun. 2019, 55, 14359-14362.

(4) Sprules, T.; Green, N.; Featherstone, M.; Gehring, K. Lock and Key Binding of the HOX YPWM Peptide to the PBX Homeoprotein. J. Biol. Chem. 2003, 278, 1053-1058.

(5) Aulisa, L.; Forraz, N.; McGuckin, C.; Hartgerink, J. D. Inhibition of Cancer Cell Proliferation by Designed Peptide Amphiphiles. Acta Biomater. 2009, 5, 842-853.

(6) Yeaman, M. R.; Yount, N. Y. Mechanisms of Antimicrobial Peptide Action and Resistance. Pharmacol. Rev. 2003, 55, 27-55.

(7) Zhang, L.; Gallo, R. L. Antimicrobial Peptides. Curr. Biol. 2016, 26, R1-R21.

(8) Ward, B. P.; Ottaway, N. L.; Perez-Tilve, D.; Ma, D.; Gelfanov, V. M.; Tschöp, M. H.; DiMarchi, R. D. Peptide Lipidation Stabilizes Structure to Enhance Biological Function. Mol. Metab. 2013, 2, 468-479.

(9) Martin, B. R.; Cravatt, B. F. Large-Scale Profiling of Protein Palmitoylation in Mammalian Cells. Nat. Methods 2009, 6, 135-138.

(10) Lockwood, N. A.; Haseman, J. R.; Tirrell, M.V.; Mayo, K. H. Acylation of SC4 Dodecapeptide Increases Bactericidal Potency Against Gram-Positive Bacteria, Including Drug-Resistant Strains. Biochem. J. 2004, 378, 93-103.

(11) Forns, P.; Lauer-Fields, J. L.; Gao, S.; Fields, G. B. Introduction of Protein-like Molecular 
Architecture by Monoalkyl Hydrocarbon Chains. Biopolymers 2000, 54, 531-546.

(12) Löwik, D. W. P. M.; Garcia-Hartjes, J.; Meijer, J. T.; van Hest, J. C. M. Tuning Secondary Structure and Self-Assembly of Amphiphilic Peptides. Langmuir 2005, 21, 524-526.

(13) Löwik, D. W. P. M.; Linhardt, J. G.; Adams, P. J. H. M. van Hest, J. C. M. Non-Covalent Stabilization of a $\beta$-Hairpin Peptide into Liposomes. Org. Biomol. Chem. 2003, 1, 1827-1829.

(14) Qahwash, I. M.; Boire, A.; Lanning, J.; Krausz, T.; Pytel, P.; Meredith, S. C. Site-Specific Effects of Peptide Lipidation on $\beta$-Amyloid Aggregation and Cytotoxicity. J. Biol. Chem. 2007, 282, 36987-36997.

(15) Makovitzki, A.; Avrahami, D.; Shai, Y. Ultrashort Antibacterial and Antifungal Lipopeptides.

Proc. Natl. Acad. Sci. U. S. A. 2006, 103, 15997-16002.

(16) Makovitzki, A.; Baram, J.; Shai, Y. Antimicrobial Lipopolypeptides Composed of Palmitoyl Diand Tricationic Peptides: In Vitro and in Vivo Activities, Self-Assembly to Nanostructures, and a Plausible Mode of Action. Biochemistry 2008, 47, 10630-10636.

(17) Hartgerink, J. D.; Beniash, E.; Stupp, S. I. Self-Assembly and Mineralization of Peptide-Amphiphile Nanofibers. Science 2001, 294, 1684-1688.

(18) Cui, H.; Webber, M. J.; Stupp, S. I. Self-Assembly of Peptide Amphiphiles: From Molecules to Nanostructures to Biomaterials. Biopolymers 2010, 94, 1-18.

(19) Hendricks, M. P.; Sato, K.; Palmer, L. C.; Stupp, S. I. Supramolecular Assembly of Peptide Amphiphiles, Acc. Chem. Res. 2017, 50, 2440-2448.

(20) Matson, J. B.; Stupp, S. I. Self-Assembling Peptide Scaffolds for Regenerative Medicine. Chem. Commun. 2012, 48, 26-33. 
(21) Hu, J.; Chen, C.; Zhang, S.; Zhao, X.; Xu, H.; Zhao, X.; Lu, J. R. Designed Antimicrobial and Antitumor Peptides with High Selectivity. Biomacromolecules 2011, 12, 3839-3843.

(22) Chen, C.; Hu, J.; Zeng, P.; Pan, F.; Yaseen, M.; Xu, H.; Lu, J. R. Molecular Mechanisms of Anticancer Action and Cell Selectivity of Short $\alpha$-Helical Peptides. Biomaterials 2014, 35, 1552-1561.

(23) Chen, C.; Chen, Y.; Yang, C.; Zeng, P.; Xu, H.; Pan, F.; Lu, J. R. High Selective Performance of Designed Antibacterial and Anticancer Peptide Amphiphiles. ACS Appl. Mater. Interfaces 2015, 7, 17346-17355.

(24) Minor, D. L.; Kim, P. S. Measurement of the $\beta$-Sheet-Forming Propensities of Amino Acids. Nature 1994, 367, 660-663.

(25) Xu, H.; Wang, Y.; Ge, X.; Han, S.; Wang, S.; Zhou, P.; Shan, H.; Zhao, X.; Lu, J. R. Twisted Nanotubes Formed from Ultrashort Amphiphilic Peptide $\mathrm{I}_{3} \mathrm{~K}$ and Their Templating for the Fabrication of Silica Nanotubes. Chem. Mater. 2010, 22, 5165-5173.

(26) Han, S.; Cao, S.; Wang, Y.; Wang, J.; Xia, D.; Xu, H.; Zhao, X.; Lu, J. R. Self-Assembly of Short Peptide Amphiphiles: The Cooperative Effect of Hydrophobic Interaction and Hydrogen Bonding. Chem.-Eur. J. 2011, 17, 13095-13102.

(27) Simister, E. A.; Thomas, R. K.; Penfold, J.; Aveyard, R.; Binks, B. P.; Cooper, P.; Fletcher, P. D. I.; Lu, J. R.; Sokolowski, A. Comparison of Neutron Reflection and Surface Tension Measurements of the Surface Excess of Tetradecyltrimethylammonium Bromide Layers at the Air/Water Interface. $J$. Phys. Chem. 1992, 96, 1383-1388.

(28) Lyu, P. C.; Sherman, J. C.; Chen, A.; Kallenbach, N. R. Alpha-Helix stabilization by Natural and Unnatural Amino Acids with Alkyl Side Chains. Proc. Natl. Acad. Sci. U. S. A. 1991, 88, 
$5317-5320$.

(29) Cui, H.; Muraoka, T.; Cheetham, A. G.; Stupp, S. I. Self-Assembly of Giant Peptide Nanobelts. Nano Lett. 2009, 9, 945-951.

(30) Miravet, J. F.; Escuder, B.; Segarra-Maset, M. D.; Tena-Solsona, M.; Hamley, I. W.; Dehsorkhi, A.; Castelletto, V. Self-Assembly of a Peptide Aphiphile: Transition from Nanotape Fibrils to Micelles. Soft Matter 2013, 9, 3558-3564.

(31) Zhao, Y.; Yang, W.; Wang, D.; Wang, J.; Li, Z.; Hu, X.; King, S.; Rogers, S.; Lu, J. R.; Xu, H. Controlling the Diameters of Nanotubes Self-Assembled from Designed Peptide Bolaphiles. Small 2018, 14, 1703216.

(32) Wang, M.; Wang, J.; Zhou, P.; Deng, L.; Zhao, Y.; Sun, Y.; Yang, W.; Wang, D.; Li, Z.; Hu, X.; King, S. M.; Rogers, S. E.; Cox, H.; Waigh, T. A.; Yang, J.; Lu, J. R.; Xu, H. Nanoribbons Self-Assembled from Short Peptides Demonstrate the Formation of Polar Zippers between $\beta$-Sheets.

Nat. Commun. 2018, 9, 5118.

(33) Aggeli, A.; Nyrkova, I. A.; Bell, M.; Harding, R.; Carrick, L.; McLeish, T. C. B.; Semenov, A. N.; Boden, N. Hierarchical Self-Assembly of Chiral Rod-Like Molecules as a Model for Peptide ß-Sheet Tapes, Ribbons, Fibrils, and Fibers. Proc. Natl. Acad. Sci. U. S. A. 2001, 98, 11857-11862.

(34) Shamovsky, I. L.; Ross, G. M.; Riopelle, R. J. Theoretical Studies on the Origin of $\beta$-Sheet Twisting. J. Phys. Chem. B 2000, 104, 11296-11307.

(35) Chen, C.; Hu, J.; Zeng, P.; Chen, Y.; Xu, H.; Lu, J. R. High Cell Selectivity and Low-Level Antibacterial Resistance of Designed Amphiphilic Peptide G(IIKK $)_{3} \mathrm{I}-\mathrm{NH}_{2}$. ACS Appl. Mater. 
Interfaces 2014, 6, 16529-16536.

(36) Chen, C.; Hu, J.; Yang, C.; Zhang, Y.; Wang, F.; Mu, Q.; Pan, F.; Xu, H.; Lu, J. R. Amino Acid Side Chains Affect the Bioactivity of Designed Short Peptide Amphiphiles. J. Mater. Chem. B 2016, 4, 2359-2368.

(37) Chen, C.; Yang, C.; Chen, Y.; Wang, F.; Mu, Q.; Zhang, J.; Li, Z.; Pan, F.; Xu, H.; Lu, J. R. Surface Physical Activity and Hydrophobicity of Designed Helical Peptide Amphiphiles Control Their Bioactivity and Cell Selectivity. ACS Appl. Mater. Interfaces 2016, 8, 26501-26510.

(38) Greenfield, N. J. Methods to Estimate the Conformation of Proteins and Polypeptides from Circular Dichroism data. Anal. Biochem. 1996, 235, 1-10. 


\section{Supporting Information}

\section{Modulation of Antimicrobial Peptide Conformation and Aggregation by Terminal Lipidation and Surfactants}

Kang Liu ${ }^{1}$, Liuxin Yang ${ }^{1}$, Xiaoting Peng ${ }^{1}$, Jiqian Wang ${ }^{1, *}$, Jian Ren $\mathrm{Lu}^{2}$, Hai $\mathrm{Xu}^{1, *}$

${ }^{1}$ State Key Laboratory of Heavy Oil Processing \& Centre for Bioengineering and

Biotechnology, China University of Petroleum (East China), Qingdao, 266580, China

${ }^{2}$ Biological Physics Group, School of Physics and Astronomy, University of Manchester,

Oxford Road, Manchester M13 9PL, UK

Corresponding authors: Jiqian Wang, jqwang@upc.edu.cn

Hai Xu, xuh@upc.edu.cn

Figures: 7

Pages: 5 
HPLC
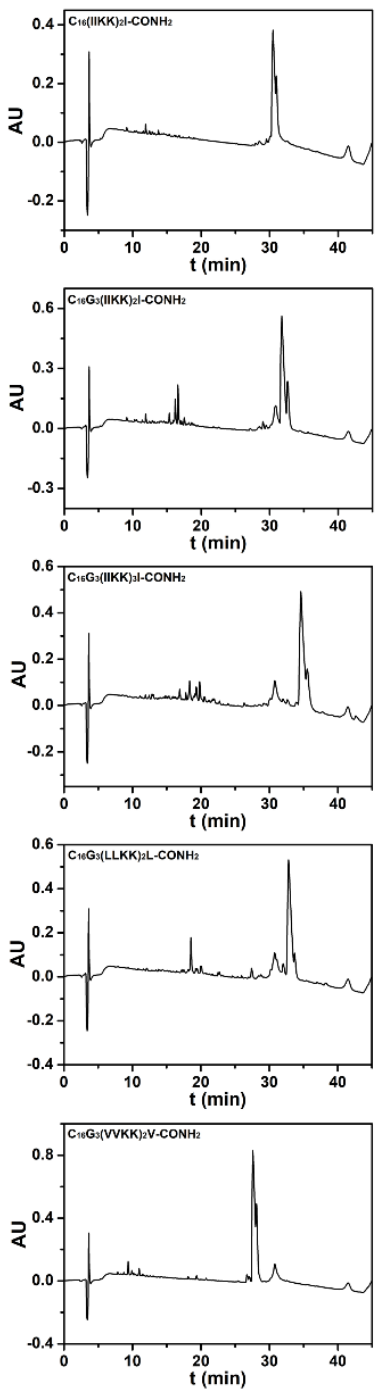
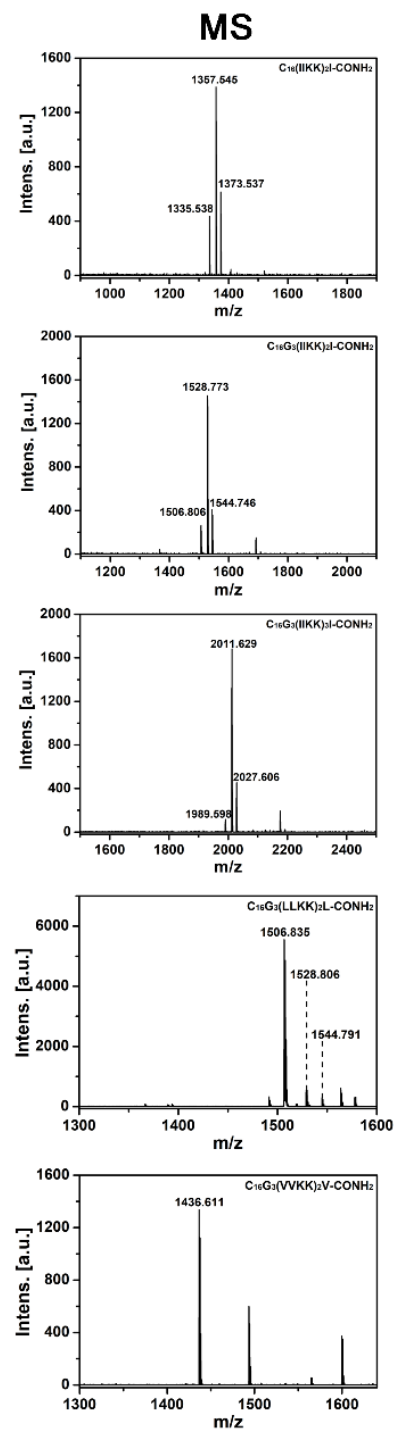

Figure S1. HPLC profiles and mass spectra of the designed lipidated peptides: $\mathrm{C}_{16}-(\mathrm{IIKK})_{2} \mathrm{I}-\mathrm{NH}_{2}, \quad \mathrm{C}_{16}-\mathrm{G}_{3}(\mathrm{IIKK})_{2} \mathrm{I}-\mathrm{NH}_{2}, \quad \mathrm{C}_{16}-\mathrm{G}_{3}(\mathrm{IIKK})_{3} \mathrm{I}-\mathrm{NH}_{2}, \quad \mathrm{C}_{16}-\mathrm{G}_{3}(\mathrm{LLKK})_{2} \mathrm{~L}-\mathrm{NH}_{2}$, $\mathrm{C}_{16}-\mathrm{G}_{3}(\mathrm{VVKK})_{2} \mathrm{~V}-\mathrm{NH}_{2}$.

HPLC profiles of lipidated peptides were recorded on a Waters 2695 Alliance HPLC system equipped with a $\mathrm{C} 18$ reversed-phase column $(4.6 \mathrm{~mm} \times 150 \mathrm{~mm})$. The eluting system consisted of eluent A $(0.1 \%(\mathrm{v} / \mathrm{v})$ TFA in water) and eluent B $(0.1 \%(\mathrm{v} / \mathrm{v})$ TFA in acetonitrile). After being loaded onto the C18 column, samples were first analyzed using an isocratic elution consisting of $95 \%$ eluent $\mathrm{A}$ and $5 \%$ eluent B for $1 \mathrm{~min}$, followed by a linear gradient elution to $5 \%$ eluent A and $95 \%$ eluent B for 39 min. Finally, a linear 
gradient elution to $95 \%$ eluent $\mathrm{A}$ and $5 \%$ eluent $\mathrm{B}$ for 5 min was applied to reset the system. Other instrumental conditions were as follows: eluent flow rate of $0.6 \mathrm{mM} / \mathrm{min}$ and UV detection at $214 \mathrm{~nm}$. The $1 \mathrm{mM}$ peptide solutions were used for this measurement.

Mass spectrometry measurements were performed on a Bruker Microflex MALDI-TOF mass spectrometer. Positive-ion mode spectra were recorded with $\mathrm{m} / \mathrm{z}$ ranging from 400 to 3150 at a laser frequency of $60 \mathrm{~Hz}$. Other instrumental parameters were as follows: ion source I voltage, $19.0 \mathrm{kV}$; ion source II voltage, $15.7 \mathrm{kV}$; lens voltage, $9.2 \mathrm{kV}$; accelerating voltage, $19.0 \mathrm{kV}$; reflection voltage, $20.0 \mathrm{kV}$; extraction delay time, $140 \mathrm{~ns}$. The matrix used in this study was 4-hydroxy- $\alpha$-cyanocinnamic acid (HCCA), which was dissolved in $30 \%(\mathrm{v} / \mathrm{v})$ acetonitrile containing $0.1 \%(\mathrm{v} / \mathrm{v})$ trifluoroacetic acid (TFA) to obtained a saturated matrix solution. For the sample preparation, $1 \mu \mathrm{L}$ of peptide solution was mixed with $1 \mu \mathrm{Lof}$ the saturated HCCA solution. Then, $1 \mu \mathrm{L}$ of the mixture solution was dropped on a polished steel sample target and air-dried, immediately followed by MS measurements. Each of the spectra collected was the integration of 100 individual measurements.

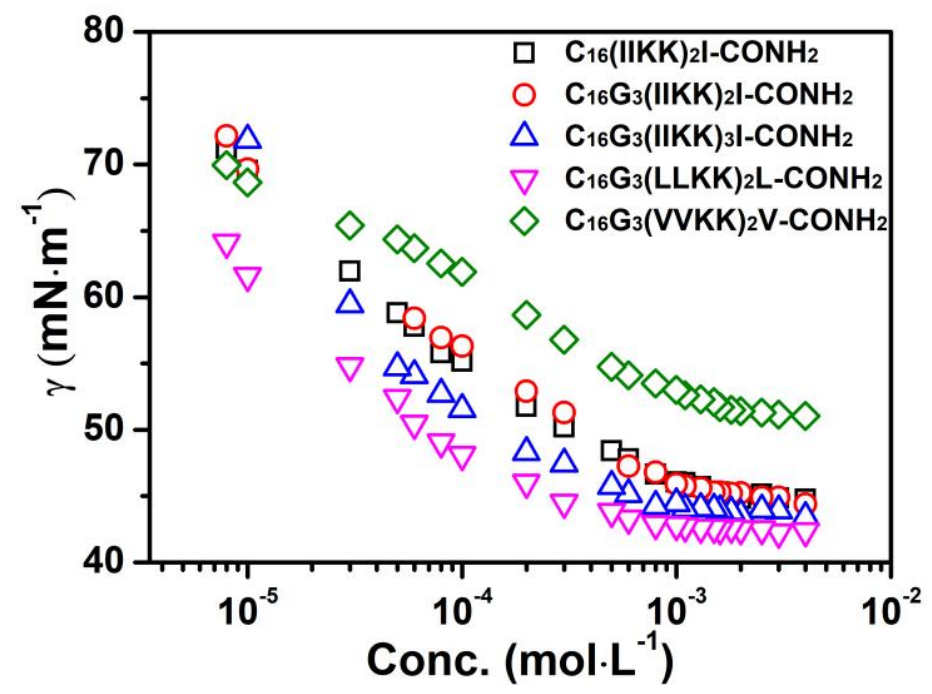

Figure S2. Plot of surface tension against concentration for the designed lipidated 
peptides in pure water at $25{ }^{\circ} \mathrm{C}: \quad \mathrm{C}_{16}-(\mathrm{IIKK})_{2} \mathrm{I}-\mathrm{NH}_{2}, \quad \mathrm{C}_{16}-\mathrm{G}_{3}(\mathrm{IIKK})_{2} \mathrm{I}-\mathrm{NH}_{2}$, $\mathrm{C}_{16}-\mathrm{G}_{3}(\mathrm{IIKK})_{3} \mathrm{I}-\mathrm{NH}_{2}, \mathrm{C}_{16}-\mathrm{G}_{3}(\mathrm{LLKK})_{2} \mathrm{~L}-\mathrm{NH}_{2}, \mathrm{C}_{16}-\mathrm{G}_{3}(\mathrm{VVKK})_{2} \mathrm{~V}-\mathrm{NH}_{2}$.
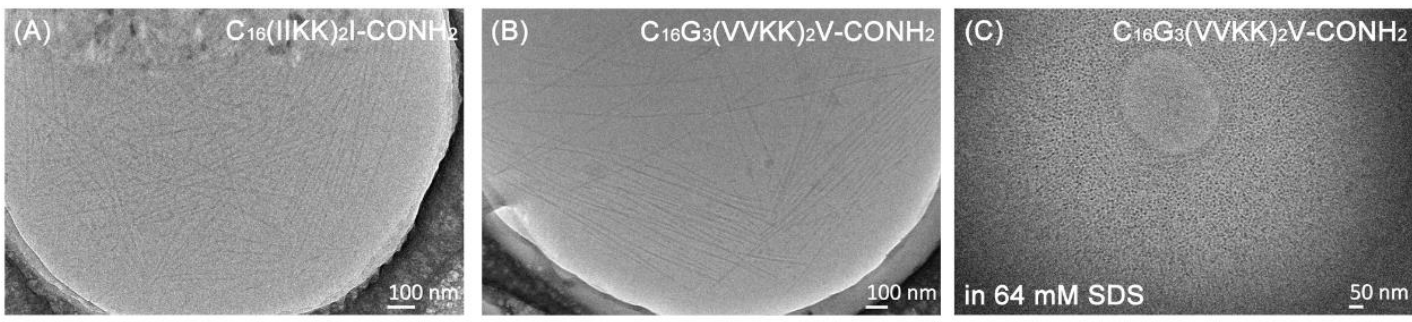

Figure S3. cryo-TEM images of (A) $1 \quad \mathrm{mM}^{-} \mathrm{C}_{16}-(\mathrm{IIKK})_{2} \mathrm{I}-\mathrm{NH}_{2}, \quad$ (B) $1 \mathrm{mM}$ $\mathrm{C}_{16}-\mathrm{G}_{3}(\mathrm{VVKK})_{2} \mathrm{~V}-\mathrm{NH}_{2}$ and $(\mathrm{C}) 1 \mathrm{mM} \mathrm{C}_{16}-\mathrm{G}_{3}(\mathrm{VVKK})_{2} \mathrm{~V}-\mathrm{NH}_{2}$ with $64 \mathrm{mM}$ SDS.

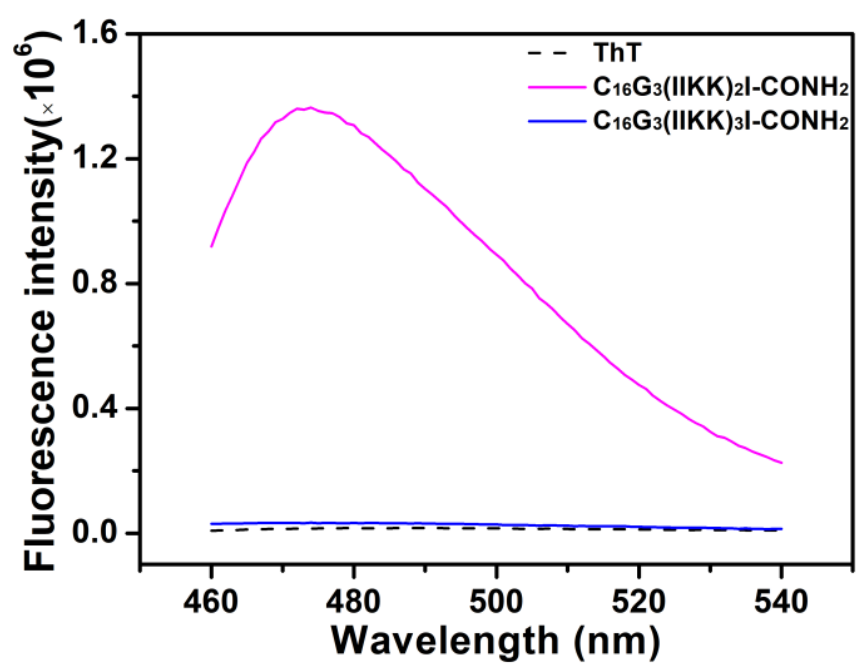

Figure S4. Fluorescence emission spectra (excitation at $442 \mathrm{~nm}$ ) of $0.05 \mathrm{mM}$ ThT in the absence and presence of $1 \mathrm{mM} \mathrm{C}_{16}-\mathrm{G}_{3}(\mathrm{IIKK})_{2} \mathrm{I}-\mathrm{NH}_{2}$ and $\mathrm{C}_{16^{-}}-\mathrm{G}_{3}(\mathrm{IIKK})_{3} \mathrm{I}-\mathrm{NH}_{2}$.
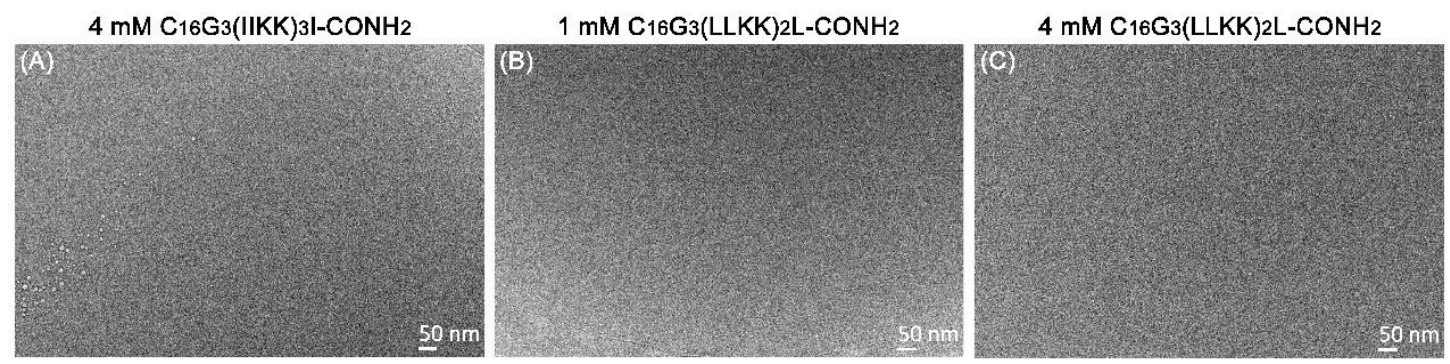

Figure S5. cryo-TEM images of (A) $4 \quad \mathrm{mM}^{-} \mathrm{C}_{16}-\mathrm{G}_{3}(\mathrm{IIKK})_{3} \mathrm{I}-\mathrm{NH}_{2}$, (B) $1 \mathrm{mM}$ 
$\mathrm{C}_{16}-\mathrm{G}_{3}(\mathrm{LLKK})_{2} \mathrm{~L}-\mathrm{NH}_{2}$ and (C) $4 \mathrm{mM} \mathrm{C}_{16}-\mathrm{G}_{3}(\mathrm{LLKK})_{2} \mathrm{~L}-\mathrm{NH}_{2}$.
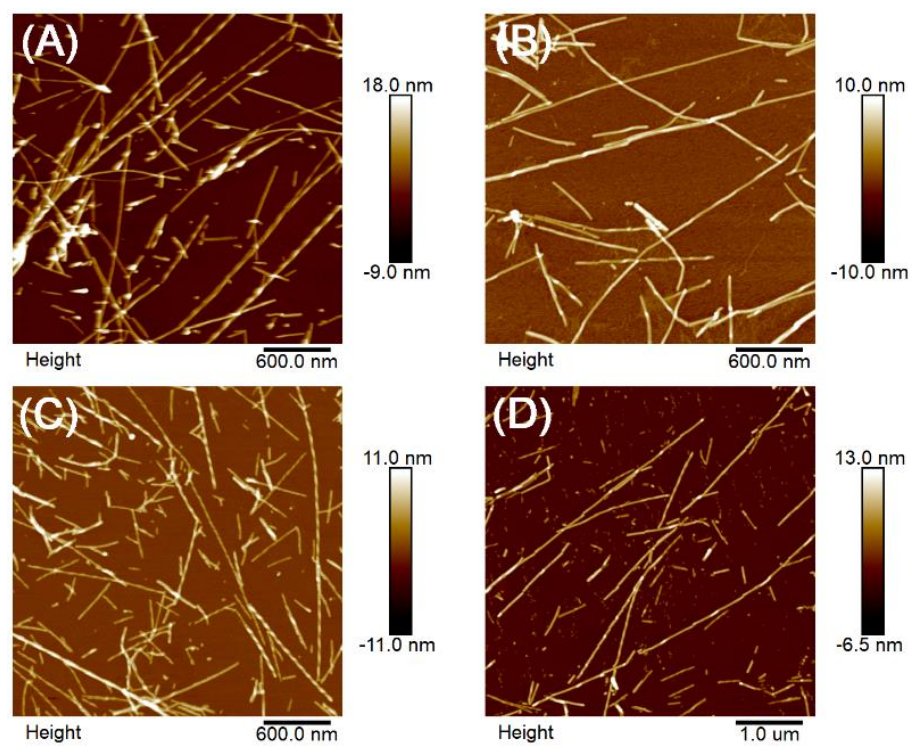

Figure S6. AFM images of (A) $\mathrm{C}_{16}-(\mathrm{IIKK})_{2} \mathrm{I}-\mathrm{NH}_{2}$, (B) $\mathrm{C}_{16}-\mathrm{G}_{3}(\mathrm{IIKK})_{2} \mathrm{I}-\mathrm{NH}_{2}$, (C) $\mathrm{C}_{16}-(\mathrm{VVKK})_{2} \mathrm{~V}_{-} \mathrm{NH}_{2}$ and (D) $\mathrm{C}_{16}-\mathrm{G}_{3}(\mathrm{VVKK})_{2} \mathrm{~V}-\mathrm{NH}_{2}$ nanofibers formed at a concentration of $1 \mathrm{mM}$ in neutral water.
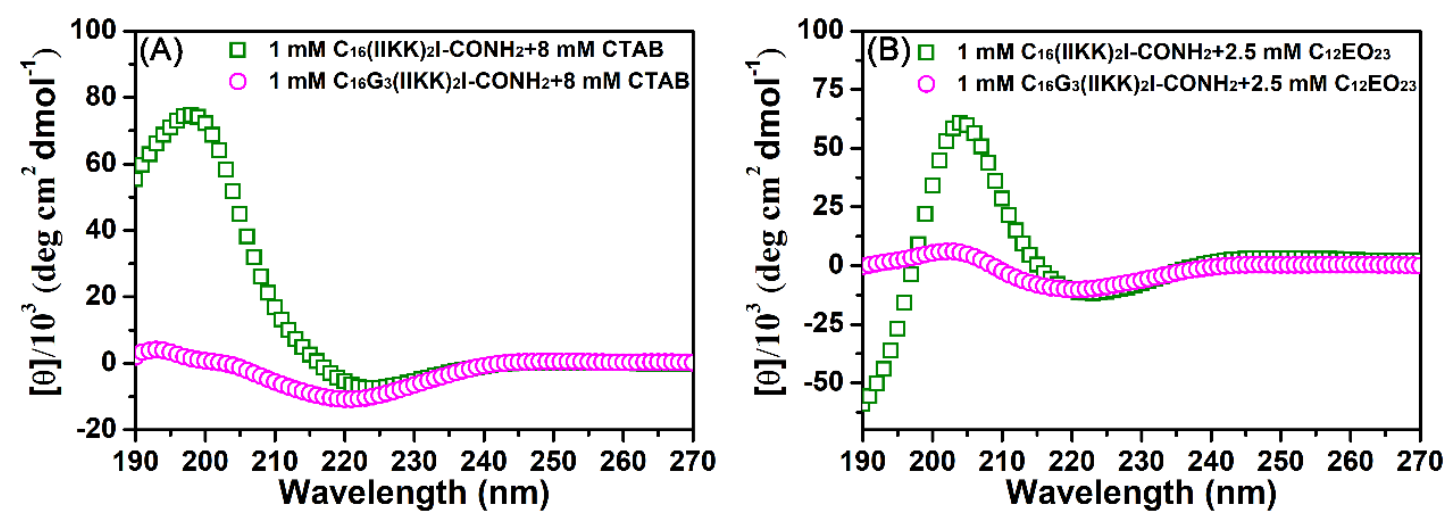

Figure S7. CD spectra of $1 \mathrm{mM} \mathrm{C}_{16}-(\mathrm{IIKK})_{2} \mathrm{I}-\mathrm{NH}_{2}$ and $\mathrm{C}_{16^{-}}-\mathrm{G}_{3}(\mathrm{IIKK})_{2} \mathrm{I}-\mathrm{NH}_{2}$ with (A) 8 $\mathrm{mM} \mathrm{CTAB}$ and (B) $2.5 \mathrm{mM} \mathrm{C}_{12} \mathrm{EO}_{23}$. 
